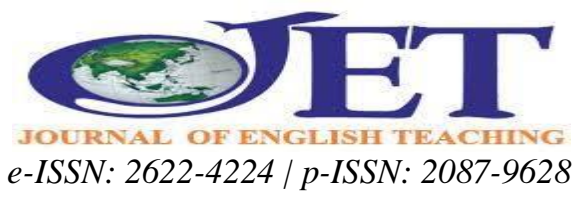

\title{
Professional Identity Tensions and Coping Strategies of EFL Pre-Service Teachers
}

\author{
Yohanes Maria Restu Dian Raharjo \\ johnmary.restu@gmail.com \\ Universitas Sanata Dharma \\ Yogyakarta, Indonesia \\ Yuseva Ariyani Iswandari \\ yuseva.iswandari@gmail.com \\ Universitas Sanata Dharma \\ Yogyakarta, Indonesia
}

\begin{abstract}
Professional identity of English teachers is an important process in which teachers view themselves as a professional based on social views about "good teacher", studentteacher relationship, and self-view as a professional teacher. Teacher preparation program such as Micro Teaching (MT) and Program Pengalaman Lapangan or PreService Teaching Practice (PTP) influences this process by providing support and opportunities in creating a strong professional identity since they are still in a preservice phase. The different nature between MT (situated) and PTP (concrete) can be challenging to the pre-service teachers (PSTs), especially during the PTP. These challenges are called professional identity tensions and they involve PSTs (as a person and professional) and undesirable situation. This study aimed to identify the professional identity tensions faced by EFL PSTs during their PTP and how they coped up with the tensions. The study employed a qualitative survey design. The results identified six professional identity tensions and two coping strategies from the story of seven EFL PSTs. Those PSTs was indicated either to feel tension or to have experiences that might lead them to tension.
\end{abstract}

Keywords: EFL pre-service teacher; professional identity tension; coping strategy

\section{INTRODUCTION}

Teacher preparation program has an impact on the on-going process of the development of teacher's professional identity. The teachers' professional identity has been highlighted to begin even before they enter the teacher preparation programs and continue to evolve as they are undergoing the programs (Chong, Low, \& Goh, 2011). Micro Teaching (MT) and Pre-Service Teaching Practice (PTP) are parts of the teacher preparation program where university students begin to be recognized as pre-service teachers (PSTs). They practice teaching under the supervision of lecturer and/or mentor (Mergler \& Spooner-Lane, 2012). Therefore, those students have to begin to act/behave like a teacher. Moreover, those teacher preparation programs (MT \& PTP) can provide 
supports and opportunities for PSTs in creating a strong professional identity as a future teacher (Beltman et al., 2015) by posing challenges, demands, and practices.

The different nature between the MT and PTP can cause struggles for PSTs, especially during the PTP. The MT is a situated teaching condition conducted in the campus by teaching classmates or juniors (Allen \& Ryan, 1969), while the PTP is a concrete one conducted in schools by teaching the school students (FKIP, 2013). Since the PSTs are demanded to act as a teacher more in the PTP, they have to struggle in the process of roles transition from being a student into being a teacher (Pillen, Beijaard, \& Brok, 2013). They also have to struggle in matching their beliefs of the teacher as a profession with the social conditions, characteristics, and demands of the school where they do their teaching practices. The struggles are defined as professional identity tensions (Pillen et al., 2013) that take place between the pre-service teachers (as a person and as a professional) and unsuitable situations. However, the tensions in professional identity do not always give negative traces. Facing the tensions are necessary for the PSTs in order to make them question about themselves (PSTs) and their beliefs (Smagorinsky et al, 2004). Should the PSTs cope with the tensions, they can gain new kinds of hope (Olsen, 2010) and can become professional teachers (Volkmann \& Anderson, 1998). In relation to that, the purpose of this study was to investigate and describe the professional identity tensions felt by the PSTs of English Language Education Study Program (ELESP) students at Sanata Dharma University, during the PPL, and to explian how they coped with those tensions.

\section{LITERATURE REVIEW}

\section{Professional Identity Tensions of Pre-Service Teachers}

Pre-service teacher's (PST) professional identity tension concerns with the process of professional identity development. In that process, the PSTs begin to interpret and reinterpret how they view themselves as a professional based on social and policy expectation about being a good teacher, teacher-students' relationship (Chong, Low, \& Goh, 2011), implement self-views of teacher as a professional at school, and meet the demands from institute and school (Beijaard, Meijer, \& Verloop, 2004). At the beginning of teaching, pre-service teachers are more likely to experience the conflicts between the reality of a teacher as a profession and their personal views, beliefs, or desires as teachers (Beijaard et al., 2004). They might find that their views as a teacher sometimes do not match the reality in their teaching practices and lead them to face struggles between themselves (as a person and professional) and the undesirable situations (Pillen, Beijaard, \& Brok, 2013).

Meanwhile, the professional identity tensions in the context of EFL PSTs also relate to the use of English, since language can also bring the tensions (Pillen et al., 2013), EFL PSTs might face language anxiety and the possibility of being led in having tensions. This foreign language anxiety emerges when the teachers have stress in using the target (foreign) language, whereas the use of the target language is essential in foreign language classroom as it can help students acquire the language (Klanrit \& Sroinam, 2012).

Various previous studies (Pillen et al., 2013; Klanrit \& Sroinam, 2012; İpek, 2016), have identified six types of professional identity tensions that can be derived. The first three are categorized as professional identity tensions felt by PSTs in general, and the rests are categorized as language anxiety-related factors that can lead EFL PSTs to tensions. 


\section{The Tension in Role Changing from Student to Teacher}

This tension emerges when the PSTs have to change their role from a student to a teacher when he is in school. It is characterized by three factors that influence one's general roles as a teacher, namely students, content knowledge, and experience (Pillen, Beijaard \& Brok, 2013). First, a PST might face tension when he is confused about whether to behave strictly as far as needed or to behave as always friendly in order to gain respect and get close to students. Then, he could also face tension if he did not feel knowledgeable enough to teach a certain part of the subject. Last, he might also face tension because he is less confident as the result of being inexperienced in doing teaching or administrating tasks.

\section{The Conflict between Desired and Actual Support Given to Students}

The tension is indicated by PSTs' experience who find that the students have problem(s) that might be related to their learning process or problems outside learning. The tension could emerge when PSTs face a conflict between the willingness to help the student and the self-limitation and less capacity to do so (Pillen, Beijaard, \&Brok, 2013). The possible results after overcoming this tension are the PSTs could only offer help that might be limited, or they even could not help at all.

\section{Conflicting Conceptions in Teaching}

During their teaching practice at schools, the PSTs integrate their knowledge, concepts, beliefs, and perceptions of teaching with the concrete practice in schools (Pillen et al., 2013). PSTs might find that his concept in teaching is different from his mentor's concept (Pillen et al., 2013). These differences could lead the PSTs to tension because they have to fulfill the demand although it does not always match their views. This tension could lead to two possible outcomes. First, the PSTs might succeed in dealing with the tension by being adaptive toward the difference. Second, they might not be successful thus made them quit and look for another practice school that might accept their views.

\section{Language Anxiety of Teachers}

English teachers who do not have confidence in their English proficiency might use their first language in teaching more often (Klanrit \& Sroinam, 2012). They could possibly feel anxious because they are worried about mispronouncing, misspelling, making grammatical errors, or even not knowing the meaning and/or translation of certain words (İpek, 2016). This kind of situation could lead them to tension and affect their teaching performances.

\section{Teacher's Expectations Toward English Proficiency of Students}

Teachers' expectations of the students' English proficiency can influence whether the teachers will use English in the teaching process. They might perceive that the students with poor English proficiency will be disorganized if English is used as a classroom language because those students have difficulties in understanding the teacher (Klanrit \& Sroinam, 2012). Besides, the teachers might feel unhappy and guilty if they ended up using native language (İpek, 2016). This kind of expectation can cause conflict between "ideally using English" and "realistically not/half using English", which lead the EFL PSTs to tension. The possible outcomes are whether the teacher stops using English or keep using English with the help of the native language. 


\section{The tension in Teaching Particular Language Skill}

EFL teacher can feel anxious when they have to teach a particular language skill (İpek, 2016) such as listening, speaking, reading, writing, and grammar. It is caused by several factors such as; teachers have not previously taught the certain skill, teachers do not have confidence in their language skill, or teachers perceive that one skill might be more difficult to teach than other skills. The teacher, who has to teach the language skill that he is anxious to, could face tension because he might not want to teach that skill, as he feels less knowledgeable and less experienced.

\section{Coping Strategies}

PSTs can overcome the tensions during the professional identity development by using some coping strategies (Pillen et.al, 2013). Coping is an effort that teachers make to examine and manage their tension (Admiraal, Korthagen, \&Wubbles, 2000). There are two types of coping strategies, namely emotion-focused coping behavior and problemfocused coping behavior (Lazarus \& Folkman, 1984).

Emotion-focused coping behavior is influenced by personality factors and is likely to occur when the users assume that environmental conditions cannot be modified (Lazarus \& Folkman, 1984). This coping behavior helps the user feel better but does not solve the source of problems or tensions (Galor, 2013), for example; a less confident English teacher avoids to use English in teaching. The examples of emotion-focused coping behavior are avoidance tactics, minimization, distancing, or selective attention (pay attention to things that do not harm toward self).

Problem-focused coping behavior is more dependent on the context and related to problem-solving strategies (Lazarus \& Folkman, 1984). The user of this coping behavior usually takes actions to solve the problems. For example, the teacher who has difficulty to teach grammar will give more time to prepare for his teaching. The examples of coping behavior are planning or preventive actions, active coping (actions to solve the problem), and sharing tensions (do a sharing through discussion to relieve the tension and/or find solution).

\section{METHOD}

This study employed the qualitative inquiry and qualitative survey research method. The qualitative inquiry was used to seek understanding and interpretation of human and social behavior in a particular situation (Ary et al., 2010), while the qualitative survey was administered to determine diversity or meaningful variation within a certain population (Jansen, 2010). Additionally, the survey was also employed to ask about people's beliefs, opinions, characteristics, and behaviors (Ary et al., 2010). In this study, social behavior and diversity refer to the professional identity tensions and coping strategies.

The population of this study was the EFL pre-service teachers of English Language Education Study Program, Sanata Dharma University, who conducted the PTP during July - December 2016. There were about 58 PSTs who conducted the PTP during the mentioned period of time, and 9 of them were purposively selected as the participants. The selection criteria were that these 9 PSTs conducted their PTP after their Micro Teaching in February - May 2016 and they were also considered cooperative in sharing the stories about their PTP.

The data were collected through a deep interview by asking the participants to tell their stories about their experiences during their PTP. There were 15 guided questions 
prepared for the interview. The questions were addressed to begin the interview or when the participants needed a question to guide them in giving the information. If the participant was considered to have answered the question(s) before being given, the question(s) would be skipped. The questions were developed by deriving the theories of professional identity tensions and coping strategies reviewed in the introduction section (Table 1)

Table 1:

Guided Questions for Interview

\begin{tabular}{|c|c|}
\hline Theories & Questions \\
\hline \multirow{4}{*}{$\begin{array}{l}\text { The Tension in Role } \\
\text { Changing from } \\
\text { Student to Teacher } \\
\text { (Pillen, Beijaard, \& } \\
\text { Brok, 2013) }\end{array}$} & $\begin{array}{l}\text { How did you view yourself as a teacher during the pre-service } \\
\text { teaching program in school (PTP)? }\end{array}$ \\
\hline & How did you behave toward your students? \\
\hline & $\begin{array}{l}\text { Did you ever feel that you are not knowledgeable enough to teach } \\
\text { your subject in? Explain! }\end{array}$ \\
\hline & $\begin{array}{l}\text { If you ever felt not knowledgeable enough, what did you do in } \\
\text { order to overcome that difficulty? }\end{array}$ \\
\hline \multirow{3}{*}{$\begin{array}{l}\text { Conflict between } \\
\text { Desired and Actual } \\
\text { Support Given to } \\
\text { Students(Pillen, } \\
\text { Beijaard, \& Brok, } \\
\text { 2013) }\end{array}$} & $\begin{array}{l}\text { Did you have experience of getting involved with troubled } \\
\text { student(s)? }\end{array}$ \\
\hline & (If number 5 answer is "yes") Did you help him/her? \\
\hline & (If number 5 answer is "yes") How did you help him/her? \\
\hline \multirow{4}{*}{$\begin{array}{l}\text { Conflicting } \\
\text { Conceptions in } \\
\text { Teaching(Pillen, } \\
\text { Beijaard, \& Brok, } \\
\text { 2013) }\end{array}$} & $\begin{array}{l}\text { How did you behave toward your mentor (guru pamong) during the } \\
\text { PPL? }\end{array}$ \\
\hline & $\begin{array}{l}\text { Did you and your mentor ever have an argument of different views } \\
\text { related to the teaching concepts? }\end{array}$ \\
\hline & $\begin{array}{l}\text { (If number } 9 \text { is a "yes") What did you do in responding this } \\
\text { situation (having different views of teaching? }\end{array}$ \\
\hline & $\begin{array}{l}\text { (If number } 9 \text { is a "no") In your opinion, how did your mentor } \\
\text { perceive your teaching concepts and what are the effect on your } \\
\text { teaching practices? }\end{array}$ \\
\hline \multirow{2}{*}{$\begin{array}{l}\text { EFL Related } \\
\text { Tensions(Klanrit \& } \\
\text { Sroinam, 2012), (İpek, } \\
\text { 2016) }\end{array}$} & $\begin{array}{l}\text { How often did you use English as classroom language during the } \\
\text { PTP? }\end{array}$ \\
\hline & $\begin{array}{l}\text { What made you often or rarely use English as the classroom } \\
\text { language? }\end{array}$ \\
\hline \multirow{2}{*}{$\begin{array}{l}\text { Coping } \\
\text { Strategies(Lazarus \& } \\
\text { Folkman, 1984) }\end{array}$} & $\begin{array}{l}\text { How often did you talk to your colleagues in PTP to discuss about } \\
\text { your problems? }\end{array}$ \\
\hline & $\begin{array}{l}\text { What were the effects that you felt after discussing your problem in } \\
\text { PTP with your colleagues? }\end{array}$ \\
\hline
\end{tabular}

The interview was conducted in a face-to-face setting with each participant at one time. The use of recording and note were also involved during the interview. Then, the data analysis was conducted to the interview transcripts of 9 participants. The identification of professional identity tensions and coping strategies were conducted by using the main theories that were derived from Pillen et al. (2013), Klanrit \& Sroinam 
(2012), İpek, 2016, and Lazarus \& Folkman (1984), presented in the theoretical description.

\section{FINDINGS AND DISCUSSIONS \\ Professional Identity Tension}

The interview transcriptsanalysis results showed that PSTs were indicatedeither to feel tensions or having experiences which might lead them to tensions, related to the professional identity. It was also found that each PSTs had the possibility to be indicated to feel more than one tension, or have more than one experience which might lead them to tension. Table 2 recapitulates the six types of indicated tensions identified from their indirect mentioning.

Table 2:

Types of Tension

\begin{tabular}{cc}
\multicolumn{1}{c}{ Types of Tension } & $\begin{array}{c}\text { How Many } \\
\text { Times } \\
\text { Mentioned }\end{array}$ \\
\hline $\begin{array}{l}\text { Tensions felt by PSTs in General } \\
\text { - The Tension in Role Changing from Student to Teacher }\end{array}$ & 7 \\
- Conflict between Desired and Actual Support Given to Students & 9 \\
- Conflicting Conceptions in Teaching & 5 \\
Tensions related to EFL Teaching & 2 \\
- Language Anxiety of Teachers & 6 \\
- Teacher's Expectations Toward English Proficiency of Students & 4 \\
\hline$\quad$ Tension in Teaching Particular Language Skill & \\
\hline
\end{tabular}

Table 2 showed that "conflict between desired and actual support given to students" was the most identified tension of the three professional identity tensions that were usually felt by PSTs in general. Meanwhile, "teacher's expectations toward English proficiency of students" was the most identified tension among the tensions related to EFL Teaching.

\section{Coping Strategy}

Data analysis also revealed thatthe participants tended to cope with their indicated tensions or tension-leading experiences. Two coping strategieswere identified to have been employed by EFL PSTs in order to cope with the indicated tensions or tensionleading experiences.

As shown in Table 3, problem-focused coping behavior was the most frequently identified coping strategy. Thisindicaed that most of EFL PSTs tended to cope by looking for the solution or solving the problems caused by the tensions. The following are the ways EFL PSTs coped with the indicated tensions or tension-leading experiences 
Table 3:

Types of Coping Strategy

\begin{tabular}{|c|c|}
\hline Types of Coping Strategy & How Many Times Identified \\
\hline \multicolumn{2}{|l|}{ Problem-Focused Coping } \\
\hline - Active coping & 16 \\
\hline - Preventive actions & 5 \\
\hline - Sharing tension & 3 \\
\hline \multicolumn{2}{|l|}{ Emotion-Focused Coping } \\
\hline - Minimization & 3 \\
\hline - Selective attention & 3 \\
\hline - Avoidance tactics & 2 \\
\hline - Distancing & 1 \\
\hline
\end{tabular}

\section{The conflict between desired and actual support given to students}

Several PSTs were indicated to feel this tension or had experience leading to this tension. This tension could emerge when there is a conflict between the desire to support students and the limitation as a PST (Pillen et al., 2013). After coping with this tension, the PST could either stop giving his limited support or not giving any support.

The Story of Pre-Service Teacher 3:

PST 3, for example, had an experience which could lead her to this tension when she did her teaching practice in school. She encountered some students who admitted that they did not like the English subject because they did not like their teacher.

...there were students who do not like English, also students who did not like English because did not like the teacher. However, it turned out that it was not me. It was my mentor whom they did not like. After I knew that, I asked them about my mentor and they began to reveal their stories. (PST 3)

She was surprised because she thought that the teacher might refer to her. However, she found out that the teacher mentioned by her students referred to her mentor instead. She saw this thing as a problem that could affect the English teaching and learning process. Therefore, she decided to solve this problem as far as she could while she was conducting her teaching practice in that school.

In order to solve this problem, she took advantages of the openness of her students. She gave them advice, opened their perspectives about being a teacher, gave tips to keep liking the subject while disliking the teacher.

I gave my advice to students during that ice-breaking... I told them that becoming a teacher is not easy... I also gave them several tips, such as; if they did not like the teacher, they must keep studying the subject which the teacher taught... I also tried to motivate and change their mindset so that they will not dislike their teacher. (PST 3)

Based on her story on coping the tension, it could be identified that she might have worriedness about their behavior-changes after she finished her PTP. She might guarantee that the students at least did not hate the English lesson because they did not hate their momentary teacher (PST 3) at that time. However, she might also be afraid that the students might dislike English again after she finished her PTP. As a result, she decided to solve the problem as a way to cope with that. Moreover, her strategy could 
be identified as an example of active coping (problem-focused coping), which resulted in giving limited support toward her students' problem.

\section{The Tension in Role Changing from Student to Teacher}

This tension emerged while the PSTs were in the process of changing their role from being a student to being a teacher during the teaching practice in school. This tension is characterized by three factors which influence general roles as a teacher. The factors are the student, content knowledge, and self-experience as a teacher (Pillen et al., 2013).

\section{The Story of Pre-Service Teacher 6:}

An example of PSTs indicated to feel this tension was PST 6 . He could be seen as a teacher who was not really confident. This caused him to be nervous and confused in teaching and dealing with students. He considered himself not really good at dealing with misbehaved students.

Honestly, I was still not really confident in facing students. I am still confused and nervous, especially related to the way on how I teach... I still have less confidence in teaching and dealing with students, when they misbehaved. (PST 6)

However, PST 6 was trying to overcome his indicated tension by employing strategy identified as sharing tension (a problem-focused coping). He had a discussion and sharing with his PTP colleagues who also taught English.

I often talked to my colleagues, especially with colleagues from the same major. We usually talked about lesson plan and teaching method... The discussion gave effect to me. From that, I could build confidence and become more prepared... (PST 6)

It could be seen that the coping strategy employed by PST 6 gave a positive impact. It helped him in overcoming his conflict on how to behave towards student as a teacher. At the same time, the strategy he employed gave impact in developing his competence as a teacher. It was because he did not only discuss the problem in behaving toward students but also about the lesson planning and teaching method.

\section{Conflicting Conceptions in Teaching}

This tension could emerge when PSTs have different views in teaching conceptions (methods or beliefs) with their mentor (Pillen et al., 2013). PST has to struggle in order to meet his mentor's demand as well as holds his belief in teaching.

\section{The Story of Pre-Service Teacher 2:}

PST 2 was an example of a PST with an experience that could lead her to the tension. In her story, she tried to make the learning process a fun activity for her students. Meanwhile, her mentor wanted her to focus on worksheet and explanation. It could be seen that she and her mentor have different beliefs about English language learning.

I ever tried to bring a new style in the learning process such as using games and video... it was not easy to change the habit... my mentor asked me to explain, give test items, and etc.... What I wanted was a learning process that not only focused on a worksheet because I wanted it to be fun. However, my mentor was not really pleased... (PST 2) 
However, it was obvious that she had been able to cope with this tension-leading experience. Her coping strategy could be identified as an active coping (a problemfocused strategy). She took action in order to meet her mentor's demand and keep her teaching and learning belief.

In response to this (unaccepted teaching style), I tried to merge my style and my mentor's. When my mentor saw that students gave positive response toward my teaching, he accepted it after I applied it several times. (PST 2)

She provedthat her teaching-learning style was accepted and gave a positive impact on students. At the same time, she also had successfully met her mentor's demand by also integrating his teaching style with hers. As a result, the problem posed by her tension-leading experience was solved as her belief gained acknowledgment from her mentor and her teaching style was accepted by students.

\section{Teacher's Expectations Toward English Proficiency of Students}

This indicated tension had relation with the tension of "giving support to students" and "role changing". This tension emerged when EFL PSTs encountered students with poor English proficiency. This encounter could make them hesitate in using English as a classroom language (Klanrit \& Sroinam, 2012). They would be confused about whether to be tough toward students by always using English, which was actually part of the support that they should give. However, it might also create distance between him and less proficient students.

\section{The Story of Pre-Service Teacher 7:}

PST 7 was an example of the ones who had an experience which might lead him to this tension. He conducted his teaching practice in a school that has many students with poor English proficiency.

Their level of English was as same as elementary school students. Therefore, if I had to teach them using full-English, they might sleep. They even slept when I taught them using Indonesia. I ever tried using full-English at the first two weeks of teaching in PTP. However, I found that the result was not appropriate after I gave them a quiz. The students who understood got 70-80, while those who did not understand got 10-20. It made me sad. ...I decided to decrease the use of English. (PST 7)

PST 7 was seen having the willingness to maintain the good learning environment in English subject by using English as the main language. However, the result of his method seemed to disappoint him. The students did not seem to behave and understand him the way he expected to be. It might be also possible that the perception about "the students with poor English proficiency will be disorganized if English is used as classroom language" also influenced his consideration after finding out his students' behavior during the learning process. As a result, he only had two options. First, he had to decide whether to behave strictly and keep maintaining the way he used English as part of his desired support. Otherwise, he behaved friendly by decreasing the use of English so that he could maintain communication with the students.

In the end, PST 7 seemed to choose to maintain communication with the students by decreasing the use of the English language. His action toward the indicated tension could be categorized as an act of minimization which belonged to emotion focus 
coping. The minimization could help him in teaching process although it might not fully solve students' problem related to the use of English.

\section{The Story of Pre-Service Teacher 2:}

PST 2 also had a similar experience with PST 7. She encountered students that could be categorized of having not high English proficiency (50-60\%). However, it seemed that she chose to not consider her students' English proficiency because she seemed to have a belief that learning English needs a habit.

I quite often used English because I wanted to show that the subject is English. As a result, I had to forcibly give them English whether they wanted or did not want so that they will be accustomed. Each day, I increased the intensity of using English. Although my student's proficiency is only 50-60\%, I kept using English because I believed that accustoming will help. (PST 2)

This belief might be the factor that influenced her way of teaching English towards the students. As a result, she kept behaving strictly by maintaining the use of English and even increasing it. Her action towards the students could be categorized as active coping (a problem-focused coping). She was actively solving students' problem in using English as well as maintaining her belief in teaching English.

\section{The tension in Teaching Particular Language Skill}

The indicated tension could emerge when EFL PSTs have to teach a particular language skill that they might not want to teach. EFL teacher can feel anxious when they have to teach a particular language skill (İpek, 2016) because of lack of experience, being unconfident toward their language skill, and teacher's perception toward the difficulty in teaching a certain language skill.

\section{The Story of Pre-Service Teacher 7:}

One example came from PST 7. He saw himself not having enough knowledge in teaching grammar. He perceived teaching grammar needed many preparation and anticipations.

I ever felt not knowledgeable, especially related to grammar, because there are many anticipations which need to be prepared in dealing with grammar. (PST 7)

His perception might get influenced by the fact that grammar is related to a set of rules which sometimes can be complicated to be learned by EFL learners. It was possible that his perception could trigger tension before and during the teaching process of grammar.

The anticipation way is studying before teaching. For example, I would teach the present tense. I had to know what the rules are, the examples, and the problems or cases in the present tense. (PST 7)

Even so, it could be seen that PST 7 responded this indicated tension by employing a coping strategy which was a preventive action. His preventive action was by studying and reviewing the material that he would teach. By employing the strategy, he prevented the indicated tension from emerging. The preparation he made could help him more in teaching grammar. 


\section{Language Anxiety of Teachers}

This indicated tension could occur if the PST is not confident with his English because of having low proficiency or being less confident to use. The tension emerged when PSTs had worriedness of making mistakes in using English.

The Story of Pre-Service Teacher 6:

PST 6, as an example, could be indicated as having the tension. He mentioned that he rarely used English as a classroom language during his PTP:

I used English rarely..." "..., it was possibly because I did not feel proficient enough if I spoke English. So, I preferred using the mother language instead of having difficulty. (PST 6)

Based on the interview result, PST 6 was indicated experiencing the tension because he had not been proficient enough to speak English. This affected his performance in teaching as he preferred to use mother language to avoid difficulty in teaching. However, it could be seen that PST 6 tried to cope with this tension.

I often talked to my colleagues, especially with colleagues from the same major... The discussion gave effect to me. From that, I could build confidence and become more prepared, especially we often did grammar correction. (PST 6)

PST 6 could be seen as doing a sharing tension in order to cope with his indicated tension. He tried to be more confident and improve his English proficiency in terms of grammar by doing a discussion with his PTP colleague from the same major. His coping strategy could be categorized as problem-focus coping since PST 6 focused on solving his less-proficient that triggered tension.

\section{CONCLUSION}

The findings of the research are able to identify 6 types of professional identity tensions faced by the EFL Pre-Service Teachers. Three of them were categorized as professional identity tensions felt by PSTs in general, while the others three were categorized as professional identity tensions felt only by PSTs in EFL setting. However, the findings only claimed that those PSTs were only indicated to feel or have experiences which might lead them to professional identity tensions.

Another finding of the research was that the PSTs tended to employ problemfocused coping behavior. In other words, most PSTs had a tendency to solve the problems and tensions they faced. Thus, itwas concluded that tensions emerged during the teaching preparation program, especially PTP, were essentially beneficial for the development of their professional identity as a future English teacher.

The claim wanted to open a room for suggestion and recommendation for researching EFL PSTs' professional identity tensions. The researchers recommended future researchers to conduct a deeper investigation by using not only deep interview but also PSTs' journal or diary, or school teaching experience reflection. The researchers suggested that the claim could be stronger when the PST's tensions are identified from several sources from the investigated PST. 


\section{REFERENCES}

Admiraal, W., Korthagen, F., \& Wubbles, T. (2000). Effects of Student Teachers' Coping Behaviour. British Journal of Educational Psychology, 70(1), 33-52.

Allen, W., \& Ryan, K. A. (1969). Microteaching. London: Addison-Wesley Publishing Company.

Ary, D., Jacobs, L. C., Sorensen, C. K., \& Razavieh, A. (2010). Introduction to Research in Education (8th ed.). Canada: Wadsworth Cengage Learning.

Beijaard, D., Meijer, P. C., \& Verloop, N. (2004). Reconsidering Research on Teachers' Professional Identity. Teaching and Teacher Education, 20, 107-128.

Beltman, S., Glass, C., Dinham, J., Chalk, B., \& Nguyen, B. (2015). Drawing Identity: Beginning Pre-Service Teachers' Professional Identities. Educational Research, 25(3), 225-245.

Chong, S., Low, E. L., \& Goh, K. C. (2011). Emerging Professional Teacher Identity of Pre-Service Teachers. Australian Journal of Teacher Education, 8, 50-64.

FKIP. (2013). Pedoman Pelaksanaan Program Pengalaman Lapangan. Yogyakarta: Universitas Sanata Dharma.

Galor, S. (2013, March 31). Emotion-focused coping strategies. Retrieved from Drsharongalor Wordpress: https://drsharongalor.wordpress.com/2012/03/31/emotion-focused-copingstrategies/

İpek, H. (2016). A Qualitative Study on Foreign Language Teaching Anxiety. Journal of Qualitative Research in Education, 4(3), 92-105.

Jansen, H. (2010). The Logic of Qualitative Survey Research and Its Position in The Field of Social Research Methods. Forum Qualitative Sozialforschung / Forum: Qualitative, 11(2). Retrieved from http://www.qualitative-research.net/

Klanrit, P., \& Sroinam, R. (2012). EFL Teacher's Anxiety in Using English in Teaching in Language Classroom. International Journal of Social Science and Humanity, 2, 493-496.

Lazarus, R., \& Folkman, S. (1984). Stress, Appraisal, and Coping. New York: Springer.

Mergler, A. G., \& Spooner-Lane, R. (2012). What Pre-Service Teachers Need to Know to Be Effective at Values-Based Education. Australian Journal of Teacher Education, 37(8), 65-81.

Olsen, B. (2010). Teaching for Success. Developing Your Teacher Identity in Today's Classroom. Boulder/London: Paradigm Publishers.

Pillen, M., Beijaard, D., \& Brok, P. D. (2013). Professional Identity Tensions of Beginning Teachers. Teacher and Teaching, 19(6), 23.

Smagorinsky, P., Cook, L., Moore, C., Jackson, A., \& Fry, P. (2004). Tensions in Learning to Teach: Accommodation and The Development of a Teaching Identity. Journal of Teacher Education, 55, 8-24.

Volkmann, M., \& Anderson, M. (1998). Creating Professional Identity: Dilemmas and Metaphors of a First-Year Chemistry Teacher. Science Education, 82(3), 293210. 